\title{
Effects of Various Operating Parameters on the Performance of an Air Breathing PEM Fuel Cell
}

Gopalakrishnan $C^{1}$,Kanchana. $J^{2}$, Meenatchi $M^{3}$, Sureshkumar $S^{4}$, Vizhivendhan $J^{5}$

${ }^{1}$ Professor, Dept. of Mechanical engineering, PSG Institute of Technology and Applied Research

${ }^{2}$ Professor PSG IAS, PSG College of Technology

${ }^{3,4,5}$ Student, Dept. of Mechanical engineering, PSG Institute of Technology and Applied Research

\begin{abstract}
The objective of the presented work is to study the operating parameters and their effects on the performance of an air breathing PEM fuel cell. In this study, we have theoretically calculated the losses associated with the fuel cells. The performance of the fuel cell can be determined by using the polarisation curve. Polarization curves from which the output voltage can be found are studied in detail. The drop in cell voltage occurs due to several irreversibility in the working environment. Reduction in resistance due to activation energy, mass transport and charge transport can help in increasing the performance of the Fuel cells. The performance of a fuel cell is also affected by the factors such as exchange current density, transfer coefficient. The operating parameters like pressure, temperature are varied and the performance of the PEM fuels cells is recorded.
\end{abstract}

Key words: Air breathing PEM fuel cells, polarization curve, temperature, pressure

\section{Introduction}

In the world with the need for energy there are some disadvantages with the use of fossil fuels. The disadvantages of fossil fuel is that we have only a limited amount of fossil fuels and also causes serious environmental problems such as global warming, pollution, climatic changes, etc. In the early 1970'it is found that hydrogen can be used as a surrogate for fuel cells. Fuel cells being an alternative for the conventional sources of energy are now widely used as a power source for many of the applications. A fuel cell in some aspects is similar to a battery. The fuel used in fuel cells is hydrogen which is a high energy carrier. Hydrogen is the lightest, cleanest and efficient fuel. Hydrogen's most important property is that through the electrochemical process high efficiency output can be obtained than the conventional fossil fuels. These attractive properties made fuel cells to be widely used for automobile applications. Consequently nowadays the conventional IC engines are being replaced by the fuel cells in many cars. Fuel cell is an energy converter which converts the chemical energy of fuel and oxidant into electrical energy.[1-5]

\section{Fuel cell Electrochemistry}

Due to the transfer of electrons and Gibbs energy change electrochemical reactions happen. Activation energy barrier determines the rate of an electrochemical reaction which is the movement of charge from electrolyte to electrode. The rate of the electrons released or consumed on the electrode surface is the speed of the electrochemical reaction which is the electrical 


\section{www.rspsciencehub.com}

current. Current per unit area of the electrode surface is called the current density. According to the Faraday's law, current density is proportional to the charge transferred and the consumption of reactant per unit area

$$
\mathrm{i}=\mathrm{nF} \mathrm{j}
$$

Where,

$\mathrm{i}=$ current density $\left(\mathrm{Am}^{-2}\right)$

$\mathrm{nF}=$ the charge transferred (Coulombs $\mathrm{mol}^{-1}$ )

$\mathrm{j}=$ the flux of reactant per unit area $\left(\mathrm{mol} \mathrm{s}^{-1} \mathrm{~cm}^{-2}\right)$

\subsection{Exchange Current Density}

The current in the absence of net electrolysis at zero over-potential is termed as exchange current density. It depends on the electrode nature not only the electrode dimensions but also the physical parameters. Exchange current density is concentration dependent. It is also a function of temperature, catalyst loading and catalyst specific area. Exchange current density at any temperature and pressure is given by

$i_{o}=i_{o}^{r e f} a_{c} L_{c}\left(\frac{P_{r}}{P_{r}^{r e f}}\right)^{\gamma} \exp \left(-\frac{E_{c}}{R T}\left(1-\frac{T}{T_{r e f}}\right)\right)$

$i_{o}^{r e f}=$ reference exchange current density

$\left(12.65 * 10^{-10} \mathrm{Acm}^{-2)}\right.$

$a_{c}=$ catalyst specific area $\left(800 \mathrm{pt} \mathrm{cm}^{2} / \mathrm{mg}\right)$

$L_{c} \quad=$ catalyst loading $\left(0.4 \mathrm{mg} \mathrm{pt} \mathrm{cm}^{-2}\right)$

$P_{r} \quad=$ reactant partial pressure, $\mathrm{kPa}$

$P_{r}^{r e f}=$ reference pressure, $\mathrm{kPa}$

$\gamma \quad=$ pressure dependency coefficient $(0.5)$

$E_{C}=$ activation energy $\left(66000 \mathrm{Jmol}^{-1}\right)$

$\mathrm{R}=$ gas constant $(8.314 \mathrm{~J}$ mol $\mathrm{K})$

$\mathrm{T}=$ temperature, $\mathrm{K}$

$T_{\text {ref }}=$ reference temperature $(298.15 \mathrm{~K})$

\subsection{Transfer Coefficient}

The fuel cell performance greatly depends on the transfer coefficient $(\alpha)$. $\alpha$ lies between 0 and 1 . Tafel slope can be determined by using transfer coefficient.

$b=2.3 \frac{R T}{\alpha F}$

Higher Tafel slope results in lower performance.

3. Voltage Losses
Volume 02 Issue 09 September 2020

When the electrical circuit is not closed even if supplied with reactant gases, the fuel cell will not generate any current. The cell potential must be close to the theoretical cell potential for given conditions. This potential is called the open circuit potential, is significantly lower than the theoretical potential, usually less than $1 \mathrm{~V}$. This shows that when no external current is generated there are some losses in the fuel cell. When the electrical circuit is closed with a load the potential must drop even further for the current being generated, due to unavoidable losses. The difference between the electrode potential and the equilibrium potential is called Over potential or Polarization. The polarization curve provides the output voltage of the fuel cell for a given current density loading.The fuel cell delivers a voltage depending on operating conditions such as temperature and pressure. Electrical energy is obtained only when the current is drawn, and the drop in cell voltage occurs due to several irreversibilities occurring in the fuel cell.The loss is the difference in the cell potential $\left(\mathrm{V}_{\text {irrev }}\right)$ from the theoretical potential $\left(\mathrm{V}_{\text {rev }}\right)$

$$
\mathrm{V}_{\mathrm{i}}=\mathrm{V}_{\text {rev }}-\mathrm{V}_{\text {irrev }}
$$

The actual open circuit voltage of a fuel cell is lower than the theoretical fuelcell voltage due to species crossover from one electrode through the electrolyte and internal currents. The three major losses are: activation polarization, concentration polarization, ohmic polarization.[6-9]

\subsection{Activation polarization (voltage over potential loss)}

The voltage over-potential required to overcome the activation energy of the electrochemical reaction on the catalyst is defined as activation polarisation. The activation polarisation occurs at low current density and measures theeffectiveness of a catalyst at a given temperature. This is a complex three-phase interface problem because fuel, catalyst, and electrolyte must make contact. The activation barrier is reduced by the catalyst but the voltage loss occursbecause of the slow reaction of oxygen. The total activation polarization over potential is 0.1 to $0.2 \mathrm{~V}$. It reduces the maximum potential to less than 1.0 V.It increases with current density and can be expressed as:[10-12] 
www.rspsciencehub.com

$\Delta V_{a c t}=E_{r}-E=\frac{R T}{\alpha F} \ln \left(\frac{i+i_{\text {loss }}}{i_{o}}\right)$

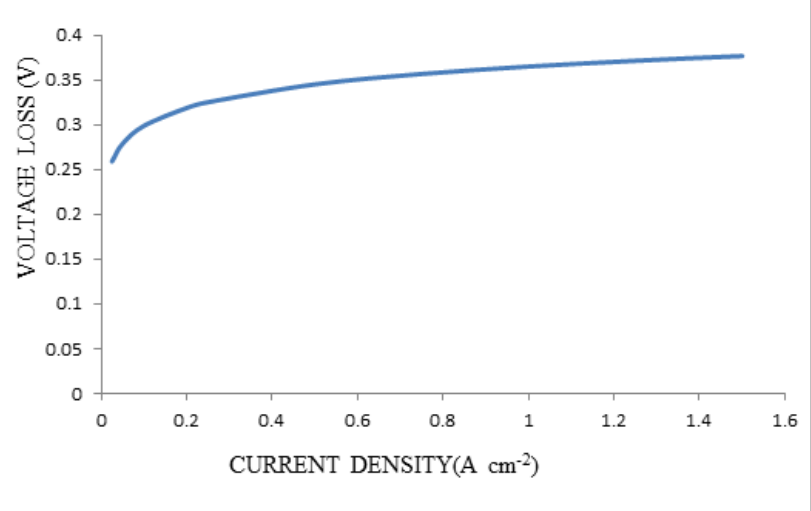

Chart.1.Activation loss

\subsection{Concentration Polarization (Mass transport voltage loss)}

Continuous supply of hydrogen and air is required to produce electricity and simultaneously the byproducts must be removed to obtain higher efficiency. The concentrations of the reactant and the product decide the fuel cell performance. The optimization of the mass transport in electrodes and flow channels can reduce the concentration loss. The mass transport is ruled by the laws of fluid dynamics since the macro scale flow channels are used. The mass transport of the electrodes takes place in a micro scale and mostly by diffusion. The concentration loss is expressed by the equation:

$v_{\text {conc }}=\frac{R T}{n F} \ln \frac{i_{L}}{i_{L}-i}$

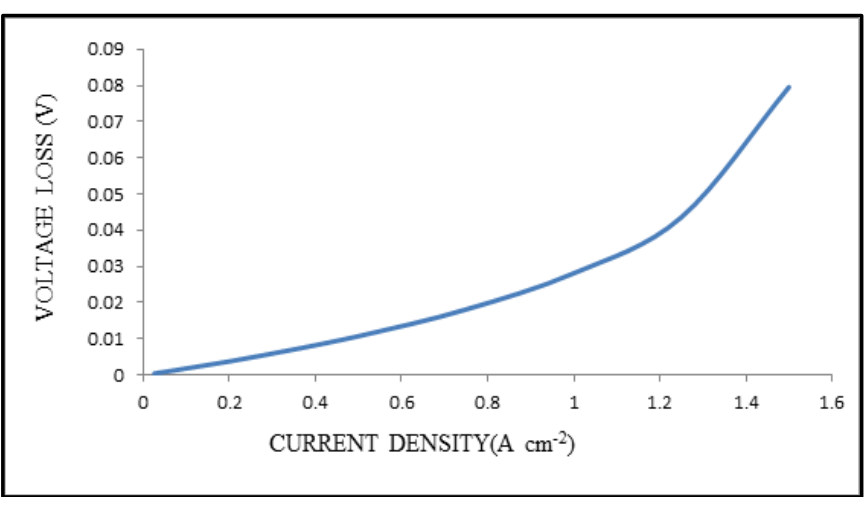

Chart.2.Concentration loss
Volume 02 Issue 09 September 2020

\subsection{Ohmic Polarization (Charge Transport Voltage Loss)}

All the conductors have resistance to electron flow which leads to voltage loss. This singularity is termed as "ohmic polarization". The electrical resistance is caused by electrolyte, catalyst layer, gas diffusion layer and bipolar plates. The voltage reduction occurs by internal ohmic losses in the fuel cell. Ohmic loss includes the electronic and ionic resistances.

This can be written as:

$v_{\text {ohmic }}=i \boldsymbol{R}_{\text {ohmic }}=\boldsymbol{i}\left(\boldsymbol{R}_{\text {elec }}+\boldsymbol{R}_{\text {ionic }}\right)$

$\mathrm{R}_{\mathrm{ohmic}}=\mathrm{ohmic}$ resistance $\left(\Omega \mathrm{cm}^{-2}\right)$.

$\mathrm{R}_{\text {ionic }}=$ resistance to the flow of ions in the electrolyte $\left(\Omega \mathrm{cm}^{-2}\right)$.

$\mathrm{R}_{\text {elec }}=$ resistance to the flow of electrons through the electrically conductive fuel cell components $\left(\Omega \mathrm{cm}^{-2}\right)$.

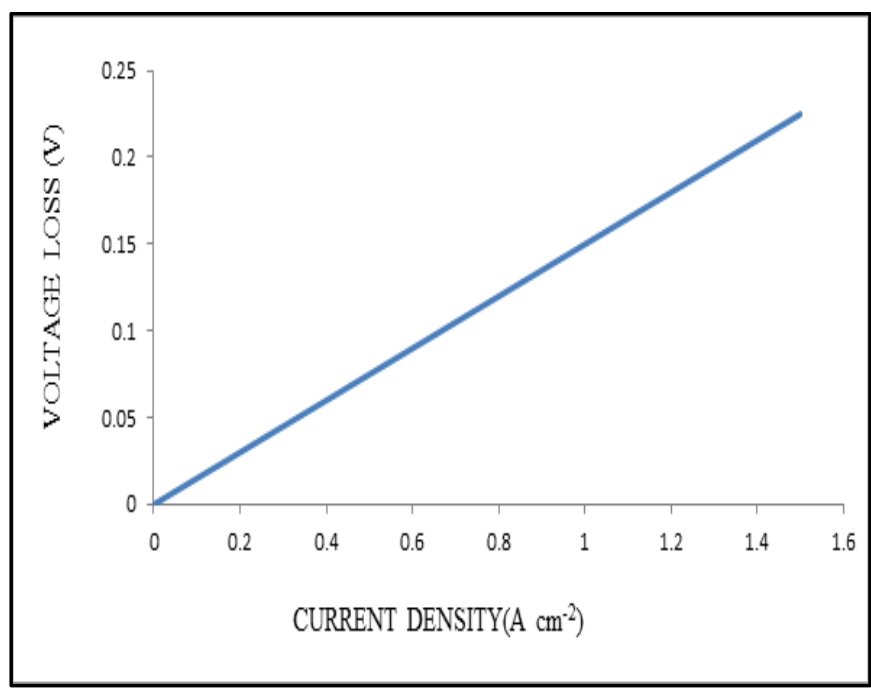

Chart.3.Ohmic loss

\section{Polarisation Curve}

The performance of a fuel cell can be measured using polarization curve, which is plotted between the cell voltage and the current density.

There are three different regions of a polarization curve: 


\section{www.rspsciencehub.com}

- At low current densities the voltage drops occur due to the activation polarization.

- At moderate current densitiesthe voltage linearly decreases due to ohmic losses.

- At high current densities the voltage drop deviates from the linearity with current density due to concentration polarization.

Net cell potential can be found by the following equation

$$
E=E_{r}-\frac{R T}{\alpha F} \ln \left(\frac{i+i_{\text {loss }}}{i_{o}}\right)-\frac{R T}{n F} \ln \left(\frac{i_{L}}{i_{L}-i}\right)-i R_{i}
$$

$E_{r}=-\left(\frac{\Delta H}{n F}-\frac{T \Delta S}{n F}\right)+\frac{R T}{n F} \ln \left(P_{H_{2}} P_{O_{2}}^{0.5} / P_{H_{2} O}\right)(9)$

$$
\begin{aligned}
& \mathrm{E} \quad=\text { net cell potential }(\mathrm{V}) \\
& \mathrm{Er} \quad=\text { reactant cell potential }(\mathrm{V}) \\
& \alpha \quad=\text { transfer coefficient } \\
& \mathrm{i} \quad=\text { current density }\left(\mathrm{Acm}^{-2}\right) \\
& \mathrm{i}_{\text {loss }}=\text { current density loss }\left(0.002 \mathrm{Acm}^{-2}\right) \\
& \mathrm{i}_{1}=\text { limiting current density }\left(1.6 \mathrm{Acm}^{-2}\right) \\
& \mathrm{R}_{\mathrm{i}}=\text { internal resistance }\left(0.15 \Omega \mathrm{cm}^{2}\right) \\
& \mathrm{P}_{\mathrm{h} 2}=\text { partial pressure of hydrogen }(1 \mathrm{bar}) \\
& \mathrm{P}_{\mathrm{o} 2}=\text { partial pressure of oxygen }(0.21 \mathrm{bar}) \\
& \Delta \mathrm{H}=\text { enthalpy change }\left(\mathrm{Jkg}^{-1}\right) \\
& \Delta \mathrm{S}=\text { entropy change }\left(\mathrm{J} / \mathrm{kgK}^{-1}\right)
\end{aligned}
$$

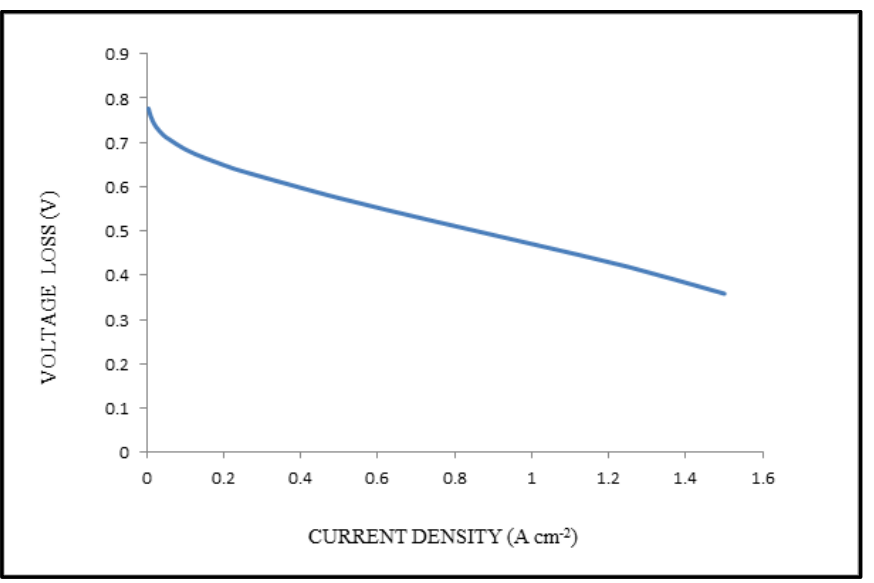

Chart.4. Polarization curve
Volume 02 Issue 09 September 2020

When the charge flow on a fuel cell is varied, heat and water balance will change and the time taken to reach a new equilibrium point will change. The equilibrium period varies with respect to the fuel cell load. Efficient VI curves require a stable environment while the tests are being conducted. The VI characteristics may change if the operating conditions are varying. The fuel cell needs some time to stabilize. Depending on the design and size the time taken to stabilize will change. The issues in the fuel cell can be solved using polarization curve. During increase and decrease of the current if the polarisation curve is plotted hysteresis will occur. Hysteresis indicates a change in fuel cell conditions, such as dehydration or flooding of the membrane. Flooding can be reduced by supplying air with pure oxygen. The difference in cell voltage should be nearly constant at any current density.

\section{Effects of Various Operating Parameters}

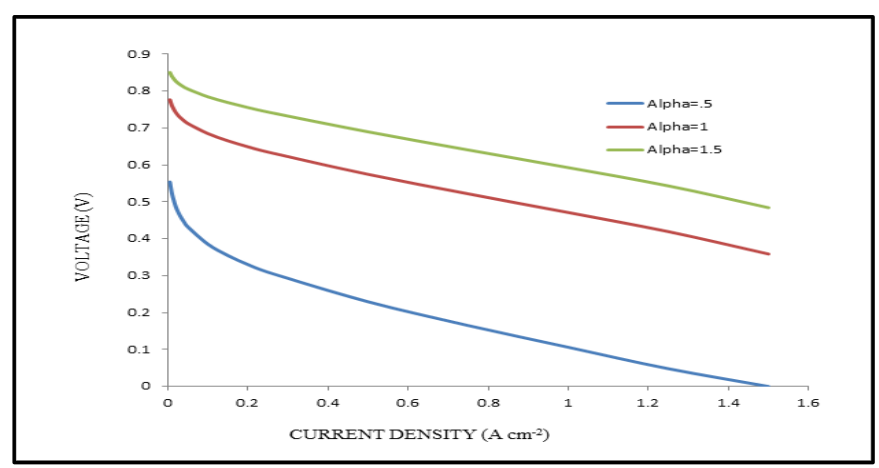

\section{Chart.5.Effect of Transfer coefficient}

From the graph we infer that transfer coefficient is directly proportional to the cell potential $a=1.5$ gives more output voltage than $\mathrm{a}=0.5$ and $\mathrm{a}=1$.

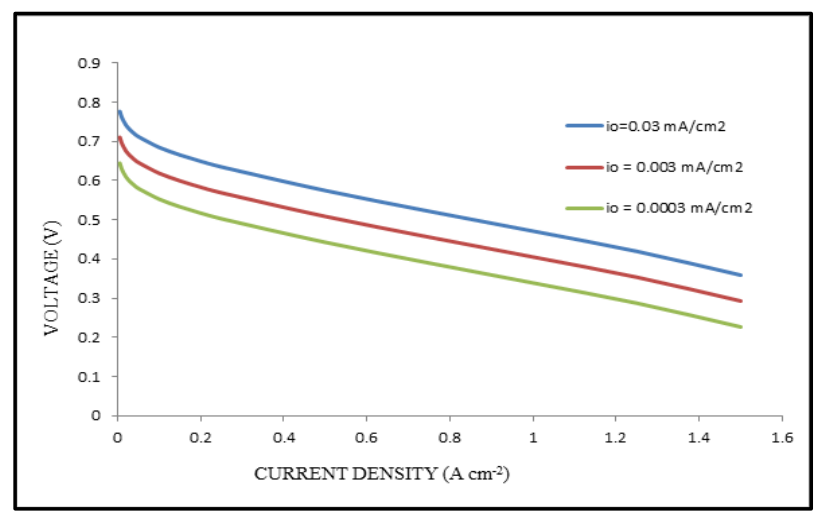

Chart.6.Effect of exchange current density 


\section{www.rspsciencehub.com}

From the graph we infer that fuel cell performance increases with the increase in exchange current density. The exchange current density is directly proportional to the voltage.

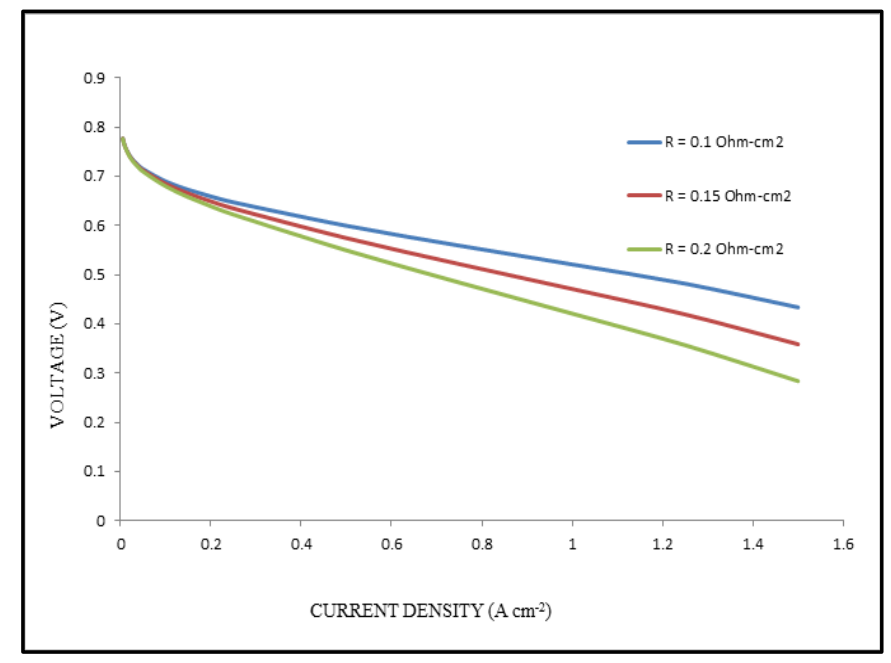

Chart.7.Effect of internal resistance

From the graph we infer that the cell potential is inversely proportional to the internal resistance. The losses due to the internal resistance decrease the output cell potential.

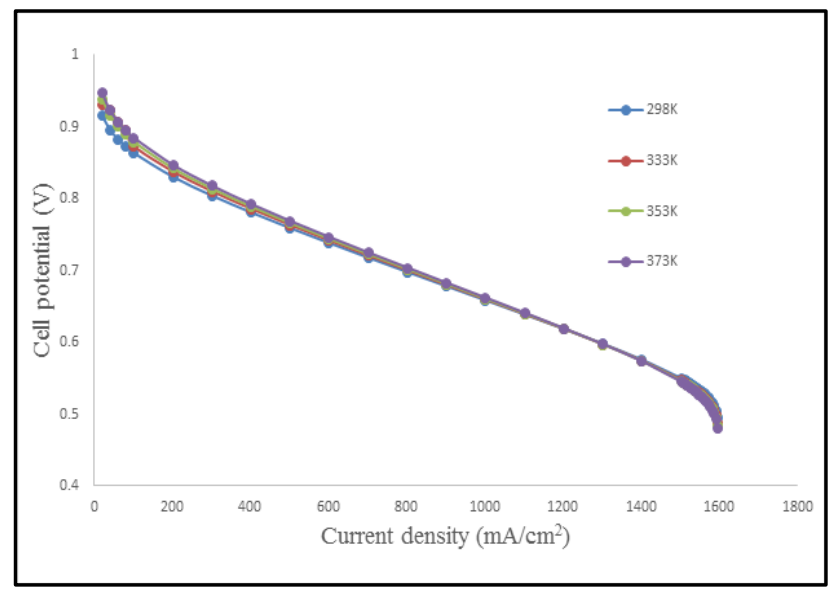

Chart.8.Effect of temperature

From the graph we infer that Fuel cell potential is directly proportional to the operating temperature. For a fuel cell, the optimum operating temperature appears between $75^{\circ} \mathrm{C}$ and $100^{\circ} \mathrm{C}$.

From the graph 9 we infer that potential is directly proportional to the pressure. Here 3 bar operating pressures give more potential than 1 bar and 2 bars.
Volume 02 Issue 09 September 2020

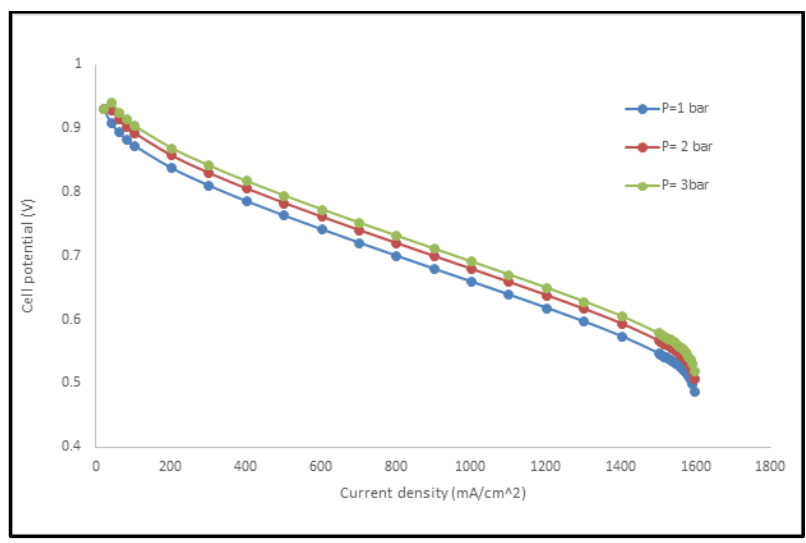

\section{Chart.9.Effect of pressure}

\section{Conclusion}

Voltage vs current density graphs are being plotted by varying the operating parameters. The polarisation curves are studied and optimum fuel cell parameters have been noted down. For the maximum performance of the Air breathing PEM fuel cells optimum values of Tafel co-efficient, Exchange current density and internal resistance are taken.

From this study we conclude that for a given condition $\left(\mathrm{p}_{\mathrm{h} 2}=1\right.$ bar $\mathrm{p}_{\mathrm{o} 2}=0.21$ bar, $\alpha=1, \mathrm{n}=2$, $\mathrm{i}_{\text {loss }}=0.002 \mathrm{Acm}^{-2}, i_{o}^{r e f}=12.65 * 10^{-10} \mathrm{Acm}^{-2}, \mathrm{a}_{\mathrm{c}}$

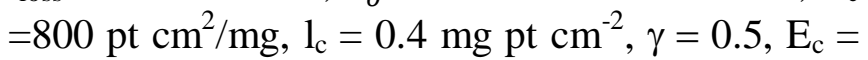
$66000 \mathrm{Jmol}^{-1}, \mathrm{i}_{1}=1.6 \mathrm{Acm}^{-2}, \mathrm{R}_{\mathrm{i}}=0.15 \Omega \mathrm{cm}^{2}$ ) a fuel-cell when operating at a pressure $3 \mathrm{bar}$ and temperature $373 \mathrm{~K}$ will give a higher output voltage.

\section{References}

[1] Baroutaji, Ahmad, et al. "Design and development of proton exchange membrane fuel cell using open pore cellular foam as flow plate material." Journal of Energy Challenges and Mechanics 1.7 (2014).

[2] Santa Rosa, D. T., et al. "High performance PEMFC stack with open-cathode at ambient pressure and temperature conditions." International Journal of Hydrogen Energy 32.17 (2007): 4350-4357.

[3] Macedo-Valencia, J., Sierra, J. M., FigueroaRamírez, S. J., Díaz, S. E., \& Meza, M. (2016). 3D CFD modeling of a PEM fuel cell stack. International journal of hydrogen energy, 41(48), 23425-23433. 


\section{www.rspsciencehub.com}

[4] Wilberforce, T., El-Hassan, Z., Khatib, F. N., Al Makky, A., Baroutaji, A., Carton, J. G., ...\&Olabi, A. G. (2017). Modelling and simulation of Proton Exchange Membrane fuel cell with serpentine bipolar plate using MATLAB. International journal of hydrogen energy, 42(40), 25639-25662.

[5] Carcadea, E., Varlam, M., Stefanescu, I., Ingham, D., Marinoiu, A., Patularu, L., ...\&Schitea, D. (2015). A CFD Simulation for an Air Breathing PEMFC for Power Source Portable Applications. ECS Transactions, 69(17), 971.

[6] Alanazi, A., Tosin, I., Nassar, F., Wilberforce, T., Vichare, P., \&Olabi, A. (2017, October). Performance evaluation of air breathing PEMFC under Saudi Arabia's ambient conditions using three-dimensional FEM model. In 12th Conference on Sustainable Development of Energy, Water and Environment Systems (SDEWES 2017), Oct 4-8, 2017, Dubrovnik, Croati

[7] Subramaniam, Shanmugasundaram, GukanRajaram, and Manoj Kumar Panthalingal. "Experimental investigation and performance analysis on 100 watts airbreathing PEM fuel cell stack." Advances in Natural and Applied Sciences 11.8 (2017): 231-2

[8] Hassan, N. U. (2016). Development of airbreathing polymer electrolyte membrane (PEM) fuel cell for small UAV application (Doctoral dissertation).

[9] Dyantyi, N., Parsons, A., Sita, C., \&Pasupathi, S. (2017). PEMFC for aeronautic applications: A review on the durability aspects. Open Engineering, 7(1), 287-302.

[10] Baroutaji, A., Carton, J. G., Stokes, J., \&Olabi, A. G. (2017). Application of Open Pore Cellular Foam for air breathing PEM fuel cell. international journal of hydrogen energy, 42(40), 25630-25638.

[11] Seo, Y. H., Kim, H. J., Jang, W. K., \& Kim, B. H. (2014). Development of active breathing micro PEM fuel cell. International Journal of Precision Engineering and Manufacturing-Green Technology, 1(2), 101106.

\section{Volume 02 Issue 09 September 2020}

[12] Flade, S., Stephan, T., Thalau, O., Burberg, T., Schirmer, J., \&Kallo, J. (2016). Air Breathing PEM Fuel Cells in Aviation. ECS Transactions, 75(14), 471. 